\title{
Seroprevalence of Bovine Viral Diarrhea Virus in Local Borana Cattle Breed and Camels (Camelus dromedarius) in Ethiopia
}

\author{
Asamenew Tesfaye' \\ Abdi Omer ${ }^{2}$ \\ Abdi Hussein ${ }^{2}$ \\ Abebe Garoma' \\ Chala Guyassa' \\ Jan Paeshuyse 3 \\ Teshale Sori Tolera ${ }^{4}$
}

'National Animal Health Diagnostic and Investigation Center, Department of Infectious Diseases, Sebeta, Ethiopia; ${ }^{2}$ Jigjiga University, College of Veterinary Medicine, Jigjiga, Somali Regional State, Ethiopia; ${ }^{3} \mathrm{KU}$ Leuven, Division of Animal and Human Health Engineering, Leuven, Belgium; ${ }^{4}$ Addis Ababa University, College of Veterinary Medicine and Agriculture, Department of Clinical Studies, Bishoftu, Ethiopia
Correspondence: Teshale Sori Tolera Addis Ababa University, College of Veterinary Medicine and Agriculture, Department of Clinical Studies, P.O.Box 34, Bishoftu, East Shewa Zone, Oromia

Regional State, Ethiopia

$\mathrm{Tel}+251911363637$

Email teshalesori2002@yahoo.com
Background: Bovine viral diarrhea, caused by bovine viral diarrhea virus (BVDV), has been considered a disease of cattle but is now emerging in camels. In Ethiopia it has been detected in exotic and cross-bred dairy cattle but no information is available on its occurrence in indigenous cattle breeds and camels. This study was, therefore, conducted to estimate the prevalence of BVDV infection in indigenous Borana cattle and camels (Camelus dromedarius) in Moyale and Miesso pastoral districts.

Methodology: Serological investigation was carried out on 219 cattle from 44 herds and 137 camels from 11 herds in contact with the selected cattle herds in Boranara zone and 348 camels from 41 herds in Shinille zone. The sera samples were tested using a competitive enzyme lnked immunosorbent assay (c-ELISA) to detect antibodies against p80 protein of BVDV. In addition, all of the cattle sera were tested using antigen detection ELISA for identification of persistent infection.

Results: Among the 219 cattle tested, 177 (80.82\%; 95\% CI: 74.97-85.81) were found to be positive for antibodies against BVDV in Moyale district, Borena Zone. The prevalence varied among different age groups and parity. The highest prevalence was observed in cattle aged 8 years and older $(84.0 \%$; 95\% CI: $69.6-98.4)$ and in primiparous cattle $(85.5 \% ; 95 \%$ CI: 76.2-94.8). Two of the 219 cattle tested $(0.05 \%$; $95 \%$ CI: $0.02-0.08)$ were found to be positive with antigen detection ELISA. In addition, out of a total of 137 camels tested, two $(1.46 \%$; $95 \%$ CI: $0.18-5.17)$ were found to be positive in this district. Among the 348 camels tested, eight $(2.29 \%$; 95\% CI: $0.99-4.485)$ were found to be positive for antibodies against BVDV. In conclusion, this study revealed a high prevalence of infection in Borana cattle. In addition, it recorded the occurrence of infection with BVDV in camel herds. None of the camels tested positive for the antigen of BVDV using antigen ELISA.

Keywords: BVDV, Borana cattle, camels, ELISA, persistent infection, Ethiopia

\section{Introduction}

Bovine viral diarrhea (BVD) is a viral disease, caused by a bovine viral diarrhea virus (BVDV), which belongs to the genus Pestivirus of the family Flaviviridae. ${ }^{1}$ BVDV consists of two genotypes designated as BVDV-1 and BVDV-2 ${ }^{2,3}$ each of which has both cytopathic and non-cytopathic biotypes. ${ }^{4}$ Mutations of the non-cytopathic biotypes can result in the emergence of cytopathic biotypes. The non-cytopathic biotypes are known to cause persistent infection in animals, which are a major source of the virus for susceptible animals. ${ }^{5}$ The biotypes of BVDV determine the epidemiology and pathogenesis of the disease both in cattle and camels since they are prevalent in both host species. ${ }^{7-9}$ 
Bovine viral diarrhea occurs worldwide and is one of the notifiable diseases of the World Organization for Animal Health. It causes significant economic losses due to reduced milk yield, extended calving intervals, and increased number of services per conception and abortion. ${ }^{10-13}$ BVD can also result in immune suppression, ${ }^{14}$ predisposing animals to other infections and bovine respiratory disease complex (BRD) if co-infection occurs with other respiratory viruses. ${ }^{15}$ It is known to affect different mammalian species belonging to Antilocapridae, Camelidae, Cervidae, Giraffidae, Suidae, Tragulidae families and small ruminants, ${ }^{16-19}$ although it is mainly a disease of cattle. ${ }^{20}$

Although it has been widely recognized in cattle, BVD is an emerging disease in camels, ${ }^{21}$ which acquire the virus while sharing pastureland with cattle. ${ }^{22}$ It has been shown that both old world and new world camels are susceptible to BVDV infection. ${ }^{22}$ In camels the disease is characterized by diarrhea, ill-thriftiness, reproductive wastage as well as respiratory signs. ${ }^{23-25}$ Studies have shown that BVDV was prevalent in $3.9 \%$ of camels in Tunisia, ${ }^{26} 16 \%$ of camels in Sudan, ${ }^{27,28}$ $3.4 \%$ of camels in Somalia, ${ }^{29}$ and 52.5\% of camels in Egypt. ${ }^{30}$

The Shinille and Borana pastoral zones of Ethiopia are characterized by the presence of large number of cattle and camels. ${ }^{31}$ In these areas cattle and camels serve the pastoral community as sources of cash income, food, power and collaterals. They are an integral part of pastoralism where cattle, camels and small ruminants are often comingled at communal pastureland in both zones. Therefore, transmission of BVDV from cattle to camels could be common. Although the occurrence of BVD in exotic and cross-bred dairy cattle is a well-established fact, information on its occurrence in local cattle breeds and camels is lacking. Since persistently infected animals serve as sources of the virus to susceptible animals and play important roles in the epidemiology of the disease ${ }^{32,33}$ their identification is important for understanding of its epidemiology. This will help the livestock and veterinary authorities pertinent to the pastoral areas to devise preventive and control measures. Therefore, the objectives of this study were to estimate prevalence of persistent infection with BVDV and associated risk factors in camels (Camelus dromedarius) and local cattle breeds in Borana and Shinilie pastoral zones, Ethiopia.

\section{Materials and Methods}

\section{Study Areas}

The study was conducted in Moyale district of Borana zone and Miesso district of Shinille zone of Ethiopia. Moyale is geographically located $567 \mathrm{~km}$ southeast of Addis Ababa between $03^{\circ} 37^{\prime} 23.8^{\prime \prime}-05^{\circ} 02^{\prime} 52.4^{\prime \prime} \mathrm{N}$ latitude and $37^{\circ}$ $56^{\prime} 49.4^{\prime \prime}-39^{\circ} 01^{\prime} 101^{\prime \prime} \mathrm{E}$ longitude. Pastoralism is the means of livelihood of the millions of the Borana community in which cattle and camels constitute the important animal species. ${ }^{31}$

Miesso district is located between $09^{\circ} 41^{\prime} \mathrm{N}$ latitude and $41^{\circ} 51^{\prime} \mathrm{E}$ longitude having an average altitude of 1079 meters above sea level. ${ }^{34}$ The majority of the inhabitants in the study areas are pure pastoralists for whom livestock production constitutes the only means of livelihood. Camels, small ruminants and cattle are important animal species in the zone. ${ }^{31}$

\section{Study Population, Design and Sample Size}

The study population considered in this study consists of cattle and camels of both sexes and different age groups reared in the selected districts. Indigenous breeds of cattle (Borana cattle) reared in Moyale district, that were above 6 months of age were included in the study. In addition, camels above 6 months of age belonging to Borana type (from Moyale district) and Somali type (from Miesso district) were included in the study. All cattle and camels that constitute the study population have no history of vaccination since no vaccine is in use in Ethiopia against BVDV. Cross-sectional design was employed to collect samples from study animals. Two-stage clustered sampling technique was used to select the herd (first stage) and individual animals (second stage) for collection of blood samples.

The number of herds required for this study was estimated using the formula described for clustered sampling approach $^{35}$ considering 95\% confidence interval. For Moyale district since there is no predetermined intracluster correlation coefficient, $\rho$ (roh) for BVD was presumed to be 0.3 , an expected prevalence of $32.6 \%{ }^{36}$ with absolute precision of $10 \%$ was used to compute the sample size for cattle. Accordingly, a minimum of 50 herds and 250 individual cattle was needed from each district. However, 219 cattle from 44 herds were sampled due to unavailability of some of the herds since they moved in search of pasture and water. So five cattle were sampled from each herd except one herd from which four cattle were sampled using convenient sampling technique. From this district 137 camels from 11 herds that were in contact with the selected cattle herds were also sampled. In Miesso district, only 348 camels from 41 herds were sampled since cattle producers were not willing to participate. 


\section{Sample Collection}

Cattle and camels included in the study were restrained properly by pastoralists to enable blood sample collection. Plain vacutainer tubes and 18 gauge needles were used to puncture the jugular vein and draw blood from each animal. The vacutainer tubes containing blood samples were kept at a slant position overnight at room temperature to allow separation of serum. The sera samples were harvested into labeled cryovial tubes and stored at $-20^{\circ} \mathrm{C}$ at Yabello Regional Veterinary Laboratory and Miesso Veterinary Clinic. The serum samples were transported to National Animal Health Diagnostic Investigation Center (NAHDIC) using an ice box containing an ice pack. The samples were stored at $-20^{\circ} \mathrm{C}$ until laboratory analysis.

\section{Serological Tests Employed Antibody Detection ELISA}

Anti-bovine BVDV p80 antibody competitive ELISA (ID.Vet, rue Louis Pasteur-Grabels, France) having a sensitivity and specificity of $100 \%$ was used to detect the presence of circulating antibodies in the serum following the manufacturer's instruction. Briefly, the samples to be tested and controls were added to the microwells and incubated at $37^{\circ} \mathrm{C}$. An anti-p80horseradish peroxidase (HRP) conjugate was added to the wells and incubated at $37^{\circ} \mathrm{C}$. The plate was removed by washing and the substrate solution (TMB) was added to each well and incubated at $37^{\circ} \mathrm{C}$. After adding the stop solution, the microplate was read using ELISA reader at $450 \mathrm{~nm}$ wavelength. The test was valid if the mean values of the optical density of the negative control $\left(\mathrm{OD}_{\mathrm{NC}}\right)$ to optical density of the positive control $\left(\mathrm{OD}_{\mathrm{PC}}\right)$ were greater than 0.7 and the ratio of the optical density of the positive control to the negative control $\left(\mathrm{OD}_{\mathrm{PC}} / \mathrm{OD}_{\mathrm{NC}}\right)$ is less than 0.3. The percent competition of each sample ( $\mathrm{S} / \mathrm{N} \%$ ) was computed using the formula described in the test protocol:

$$
\mathrm{S} / \mathrm{N} \%=\mathrm{OD}_{\text {sample }} / \mathrm{OD}_{\mathrm{NC}} \mathrm{X} 100
$$

The result was interpreted as positive, doubtful and negative when the $\mathrm{S} / \mathrm{N} \%$ was $\leq 40,40-\leq 50$ and $>50 \%$, respectively.

\section{Antigen Detection ELISA}

Since not all animals give antibody positive results, the serum samples from antibody negative animals were tested using BVDV p80 antigen capture ELISA (ID.Vet, rue Louis Pasteur-Grabels, France) according to the manufacturer's instructions. Briefly, $50 \mu \mathrm{L}$ of dilution buffer was added into each microwell and $20 \mu \mathrm{L}$ of both positive and negative controls and $50 \mu \mathrm{L}$ of test sample were added. The plate was incubated at $37^{\circ} \mathrm{C}$ $\left( \pm 2^{\circ} \mathrm{C}\right)$ for $60 \min \pm 6 \mathrm{~min}$ and the plate was washed 5 times with $300 \mu \mathrm{L}$ of wash solution. One hundred $\mu \mathrm{L}$ of conjugate diluted $1: 10$ was added and incubated at $37^{\circ} \mathrm{C}$ $\left( \pm 2^{\circ} \mathrm{C}\right)$ for $30 \mathrm{~min} \pm 3 \mathrm{~min}$. The plate was washed 3 times with $300 \mu \mathrm{L}$ of wash solution and $100 \mu \mathrm{L}$ of substrate was added and incubated at $21^{\circ} \mathrm{C}\left( \pm 5^{\circ} \mathrm{C}\right)$ for $15 \mathrm{~min} \pm$ $2 \mathrm{~min}$. Finally, $100 \mu \mathrm{L}$ of stop solution was added and the result read at $450 \mathrm{~nm}$. The test was valid if the OD of the positive control (ODpc) was greater than 0.5 and the ratio of the mean value of the OD of the positive and negative controls (ODpc/ODnc) was greater than 3. In order to interpret the test result, the sample to positive percentage ( $\mathrm{S} / \mathrm{P} \%$ ) of each sample was computed using the following formula

$$
\mathrm{S} / \mathrm{P} \%=\frac{\text { OD sample }-\mathrm{OD}_{\mathrm{NC}} \mathrm{X} 100}{\mathrm{OD}_{\mathrm{PC}}-\mathrm{OD}_{\mathrm{NC}}}
$$

Samples with S/P\% less than $35 \%$ and greater or equal to $35 \%$ were considered negative and positive, respectively.

\section{Statistical Analysis}

The data collected during this study were analyzed using SPSS version 20 statistical software (SPSS Inc., Chicago, IL, USA). 'The association between the seroprevalence of BVDV and potential predictors was analyzed using logistic regression in which the odds ratio was used to estimate the effect size. The logistic regression analysis was done only for Moyale district where both cattle and camels were tested and sufficient numbers of animals were found positive. In contrary in Miesso district where only camels were tested and only eight animals were positive out of 348 tested statistical tests were not used. The relationship between the predictors and the seroprevalence of the BVD was estimated using Maximum likelihood. Association of parity and abortion on the seroprevalence of BVDV was analyzed only for female animals. The differences were considered significant if the $p$-value is $<0.05$.

\section{Results}

\section{Prevalence of BVD in Borana Zone}

From a total of 219 cattle tested, $177(80.82 \%$; 95\% CI: 74.97-85.81) were found positive for antibodies against BVDV (Table 1). The prevalence varied among different age groups and parity. The highest prevalence was observed 
Table I Seroprevalence of BVD in Borana Cattle in Moyale District, Southern Ethiopia $(n=219)$

\begin{tabular}{|c|c|c|c|c|c|}
\hline Variables & No. Sampled & No. Positive & Prevalence $(95 \% \mathrm{CI})$ & $\chi^{2}$ & P-value \\
\hline \multicolumn{6}{|l|}{ Age } \\
\hline$<3$ & 16 & 8 & $50.0[25.4-74.5]$ & \multirow[t]{3}{*}{10.6} & \multirow[t]{3}{*}{0.05} \\
\hline $3-8$ & 178 & 148 & 83.1 [77.5-88.5] & & \\
\hline$>8$ & 25 & 21 & $84.0[69.6-98.4]$ & & \\
\hline \multicolumn{6}{|l|}{ Sex } \\
\hline Male & 22 & 18 & 81.8 [65.7-97.9] & \multirow[t]{2}{*}{0.016} & \multirow[t]{2}{*}{0.90} \\
\hline Female & 197 & 159 & $80.7[75.2-86.2]$ & & \\
\hline \multicolumn{6}{|l|}{ Parity } \\
\hline Nulliparous & 20 & 12 & $60.0[38.5-81.5]$ & \multirow[t]{3}{*}{6.43} & \multirow[t]{3}{*}{0.04} \\
\hline Primiparous & 55 & 47 & 85.5 [76.2-94.8] & & \\
\hline Pluriparous & 122 & 100 & $82.0[75.2-88.8]$ & & \\
\hline \multicolumn{6}{|l|}{ Pregnancy } \\
\hline Yes & 38 & 9 & $76.3[62.8-89.8]$ & \multirow[t]{2}{*}{0.584} & \multirow[t]{2}{*}{0.445} \\
\hline No & 159 & 130 & $81.8[75.8-87.8]$ & & \\
\hline \multicolumn{6}{|l|}{ Abortion } \\
\hline Yes & 19 & 15 & $78.9[60.5-97.2]$ & \multirow[t]{2}{*}{0.042} & \multirow[t]{2}{*}{0.838} \\
\hline No & 178 & 144 & $80.0[74.1-85.9]$ & & \\
\hline Total & 219 & 177 & $80.8[74.9-85.8]$ & & \\
\hline
\end{tabular}

Note: *Statistically significant.

in cattle aged 8 years and older $(84.0 \%$; $95 \%$ CI: 69.6-98.4) and in primiparous cattle $(85.5 \%$; $95 \%$ CI: $76.2-94.8)$. The prevalence of BVD was strongly associated with the species of animals tested from Moyale district, Borana zone (Table 2). Primiparous cows and those having two and greater parities had higher odds of being infected with BVDV than nulliparous cattle while there was no statistically significant difference in seroprevalence among cattle having parity greater than two and nulliparous ones. The odds of seropositivity to BVDV exposure was statistically higher in females that had no history of abortion than those which had history of abortion.

In addition, out of a total of 137 camels tested two $(1.46 \%$; 95\% CI: 0.18-5.17) were found to be positive in this district.

\section{Detection of BVDV Antigen in Cattle}

An attempt was also made to establish the occurrence of antigen in the herds using Antigen detection ELISA. Accordingly from the total of 219 cattle sampled during the study period, two $(0.05 \%$; $95 \%$ CI: $0.02-0.08)$ were found positive with antigen detection ELISA.

\section{Prevalence of BVD in Camels in Miesso District, Shinille Zone}

A total of 348 camels were tested among which eight (2.29\%; 95\% CI: $0.99-4.485)$ were found to be positive for antibodies against BVDV. Higher seroprevalence of bovine viral diarrhea was recorded in younger camels

Table 2 Results of Logistic Regression Analysis of the Association Between Seroprevalence of BVD and Potential Risk Factors

\begin{tabular}{|l|c|c|c|c|c|c|}
\hline Variables & OR & SE & & $\mathbf{Z}$ & P-value & 95\% Confidence Interval \\
\hline Age & 1.09 & 0.07 & 1.2 & 0.213 & 0.95 & 1.3 \\
\hline $\begin{array}{l}\text { Sex } \\
\text { Male }\end{array}$ & 1.31 & 0.7 & 0.4 & 0.653 & 0.41 & 4.2 \\
\hline $\begin{array}{l}\text { Species } \\
\text { Camel }\end{array}$ & 0.003 & 0.002 & -7.9 & $<0.001$ & 0.001 & 0.01 \\
Constant & 2.46 & 1.1 & 1.9 & 0.051 & 0.99 & 6.1 \\
\hline
\end{tabular}


(6.82\%; 95\% CI: 1.43-18.66) than adults, and in camels having history of abortion $(2.38 \%$; 95\% CI: $1.03-4.64)$ than in those without history of abortion $(0.00 \%)$ whereas nearly similar seroprevalence was recorded in camels having different parities. The results of antibody ELISA performed on camels in Miesso district is given in Table 3.

Of the total of 41 camel herds tested, 10 (24.39\%; 95\% CI: 12.36-40.30) were found positive with one or more animals infected per herd with the virus. The seroprevalence of BVD was higher in herds consisting of more than 10 camels per herd. However, none of the camels tested gave positive results for the antigen using antigen detection ELISA.

\section{Discussion}

This study provides the first report of the occurrence of BVD in camels and indigenous Borana cattle in Ethiopia. Emphatically the detection of persistent infection bears important implications since persistently infected animals serve as sources of the virus to susceptible animals and play important roles in the epidemiology of the disease. ${ }^{32,33}$ It has also been shown that seropositivity is associated with the presence of persistently infected animals whereas seronegativity is associated with the absence of PI animals in a herd. ${ }^{37}$ It is clear from the results that the virus is well entrenched in the cattle population in Borana zone and is endemic. In addition, the occurrence of BVDV virus in camel populations that were in contact with the cattle herd tested was confirmed.
The overall seroprevalence of bovine viral diarrhea $(80.82 \%)$ recorded in cattle in this study in Moyale district suggests the endemicity of the disease in the area. The seroprevalence is quite high, revealing the widespread distribution of the virus for a long period of time without recognition. It is in agreement with previous reports of seroprevalence in cattle reported from various countries such as India, ${ }^{38}$ Mexico $^{39}$ and Iran. ${ }^{40}$ It conforms to the published data showing that $60-80 \%$ of cattle herds are exposed to BVDV. ${ }^{37}$ However, our observation showed a higher prevalence than the previous studies conducted in Ethiopia. Previous studies reported prevalence ranging from $9.59 \%$ to $51.9 \%$ in southwestern and central Ethiopia. ${ }^{41-44}$ The difference observed is most likely due to herding strategy, herd size, and breed of animals studied. The previous authors studied cross-bred dairy cattle reared under smallholder and commercial dairy production systems where cattle reared on individual farms are managed separately with no or minimal contact with cattle from other farms. In contrary in pastoral areas the cattle herds from various holdings often mix with one another at communal grazing and watering areas, thus contributing to the spread of the virus. The herd size per farm is also relatively small compared with the pastoral herds. The larger herd size in pastoral areas increases the contact among cattle and the chance of spread of the virus. In addition, since cross-bred cattle are mostly reared under smallholder and commercial dairy firms, they often get more veterinary attention than cattle kept under pastoral areas.

Table 3 Seroprevalence of Bovine Virus Diarrhea in Camels Tested from Miesso District, Shinille Zone, Eastern Ethiopia

\begin{tabular}{|c|c|c|c|c|}
\hline Variables & No. Tested & No. Positive & Prevalence (\%) & \\
\hline \multirow[t]{3}{*}{ Age in years } & & & & \\
\hline & $<4$ & 44 & 3 & $6.82(1.43-18.66)$ \\
\hline & $\geq 4$ & 304 & 5 & $1.64(0.54-3.79)$ \\
\hline \multirow[t]{4}{*}{ Parity } & & & & \\
\hline & Nulliparous & 115 & 3 & $2.61(0.54-7.43)$ \\
\hline & Primiparous & 67 & 2 & $2.99(0.36-10.37)$ \\
\hline & 2 parity & 166 & 3 & I.8I (0.37-5.19) \\
\hline \multirow[t]{3}{*}{ Pregnancy } & & & & \\
\hline & Yes & 297 & 8 & $2.69(1.17-5.24)$ \\
\hline & No & 51 & 0 & $0.00(0.00-5.70)$ \\
\hline \multirow[t]{3}{*}{ Abortion } & & & & \\
\hline & Yes & 336 & 8 & $2.38(1.03-4.64)$ \\
\hline & No & 12 & 0 & $0.00(0.00-26.45)$ \\
\hline Total & 348 & 8 & $2.29(0.99-4.48)$ & \\
\hline
\end{tabular}


The results of this study revealed that odds of seropositivity increased by a factor of 7.41 and 5.66 in primiparous cattle and those which had two parities compared with nulliparous ones, respectively. The increase in seroprevalence with increasing parity could be due to an increase in animals' risk of exposure to BVDV or it may be due to immunotolerance in animals in which they fail to produce antibodies detectable by the ELISA procedure employed. ${ }^{45,46}$ This observation supports the association of BVDV with the reproductive tracts of infected cattle. Similar observations have been reported in dairy cattle in western parts of Ethiopia by Tadele et al. ${ }^{44}$ This observation conforms to the fact that the virus has strong tropism for the reproductive system of infected animals. Previous investigations revealed that BVDV causes ovarian infection with possible changes in ovarian function that could lead to reduced fertility, ${ }^{6}$ although further investigation is warranted to elucidate the importance of BVD in causing reproductive failures under pastoral conditions.

The results of the current study revealed quite low levels of seropositivity of BVDV in camels. In Moyale district, Borana zone the camels that were tested were in contact with cattle. In Miesso district, Shinille zone as well, although cattle were not sampled, the camels have been herded along with cattle. Since BVDV has been known in cattle for a long time, camels might have acquired the virus from cattle. Since there is no vaccination program against BVD either in cattle or camels in the country the seroprevalence recorded in this study is due to exposure of the animals to the virus. To the best knowledge of the authors this is the first report of infection of camels with BVDV in Ethiopia. The seroprevalence observed in camels in this study is comparable to the prevalence previously reported in camels in a European zoo, ${ }^{47}$ and in dairy camels in $\mathrm{UAE},{ }^{48}$ whereas it is lower than the prevalence reported in a zoo in the USA,${ }^{49}$ in Saudi Arabia,${ }^{50}$ in Iraq,${ }^{51}$ in Nigeria ${ }^{52}$ and in Oman. Higher seroprevalence has also been reported among camels in Egypt ${ }^{30}$ and Sudan. The difference observed in the prevalence of BVD in camels between this study and the previous studies may be due to the variation in sample size, sensitivity and specificity of the tests used, camel management systems and geographic location of the study areas.

\section{Limitations of the Study}

In this study the number of animals studied was slightly lower than the sample size required. Besides, cattle were not included in this study from Miesso district, Shinille zone due to the unwillingness of the owners; their inclusion would have enabled the comparison of the occurrence of infection with BVDV in potential hosts. Indigenous cattle and camels are of primary economic importance in the study areas where pastoralists mainly depend on them. In line with their importance, this is the first serological study in indigenous cattle and camels in pastoral areas that provides the evidence of occurrence of BVDV and encourages further studies. Finally, we believe that our study would provide baseline data on the epidemiology of BVD in the pastoral areas.

\section{Conclusions}

This study revealed high prevalence of BVDV infection in Borana cattle. In addition, it recorded the occurrence of infection with BVDV in camel herds. None of the camels tested positive for persistent infection using antigen ELISA. Therefore, in order to minimize the impacts of BVD on reproductive and productive performance, the livestock and veterinary authorities pertinent to the pastoral areas should take this into account in their plans for improvement of cattle and camel production. Further investigation is warranted for better understanding of the epidemiology of the disease.

\section{Abbreviations}

BVD, bovine viral diarrhea; BVDV, bovine viral diarrhea virus; $\mathrm{BRD}$, bovine respiratory disease; c-ELISA, competitive enzyme linked immunosorbent assay; $\mathrm{CI}$, confidence interval; ELISA, enzyme linked immunosorbent assay; HRP, horseradish peroxidase; NAHDIC, National Animal Health Diagnostic Investigation Center; OD, optical density; PI, persistent infection; $\mathrm{S} / \mathrm{N}$, sample to negative control; S/P sample to positive control.

\section{Data Sharing Statement}

The data sets used and/or analyzed in this study are available from the corresponding author on reasonable request.

\section{Ethical Approval and Consent to Participate}

The livestock owners were informed and aware about the purpose of the study, and verbal informed consent was approved by the Ethical Review Board of NAHDIC. Besides, permission to visit the study sites and to collect the blood sample from cattle and camels was obtained from the Borana and Shinille zones Livestock and Fishery Office, District Administration Office and 
community leaders of each study site. Blood sample collection was carried out under aseptic conditions by experienced veterinary laboratory technicians.

\section{Acknowledgments}

We would like to thank the Borana and Shinille zone Livestock and Fishery Bureau and the district offices and administration offices, livestock owners and community leaders for their kind cooperation during the study.

\section{Author Contributions}

All authors made a significant contribution to this work, including the conception of the study, design, collection of data, analysis and interpretation of the results. All took part in drafting, revising or critically reviewing the article; gave final approval of the version to be published; have agreed on the journal to which the article has been submitted; and agree to be accountable for all aspects of the work.

\section{Funding}

This study was financially supported by National Animal Health Diagnostic Investigation Center, Sebeta, Ethiopia.

\section{Disclosure}

The authors reported no conflicts of interest for this work.

\section{References}

1. Bielefeldt-Ohmann H. Special issue: bovine viral diarrhea virus and related pestiviruses. Viruses. 2020;12(10):1181. doi:10.3390/ v12101181

2. Heinz FX, Collett MS, Purcell RH, et al. Family Flaviviridae. In: van Regenmortel MHV, Fauget CM, Bishop DHL, et al., editors. Virus Taxonomy. Seventh Report of the International Committee of Viruses. San Diego: Academic Press; 2000:859-888.

3. Becher P, Thiel HJ. Genus Pestivirus (Flaviviridae). In: Tidona CA, Darai G, editors. The Springer Index of Viruses. Heidelberg, Germany: Springer-Verlag; 2002:327-331.

4. Baker JC. Bovine viral diarrhea virus: a review. J Am Vet Med Assoc. 1987;190:1449-1458.

5. Grooms DL, Keilen ED. Screening of neonatal calves for persistent infection with bovine viral diarrhea virus by immunohistochemistry on skin biopsy samples. Clin Diagn Lab Immunol. 2002;9:898-900.

6. Evermann JF, Berry ES, Baszler TV, et al. Diagnostic approaches for the detection of bovine viral diarrhea (BVD) virus and related pestiviruses. J Vet Diagn Invest. 1993;5:265-268.

7. Mattson DE. Viral diseases. Vet Clin North Am Large Anim Pract. 1994;10:345-351.

8. Hegazy AA, Fahmy LS, Saber MS, et al. Bovine virus diarrhea infection causes reproductive failure and neonatal mortality in the dromedary camel. Proceedings of the International Meeting on Camel Production and Future Perspectives. Al Ain, UAE. 1998; 2-3.
9. Grein M. Bovine viral diarrhea in a dairy herd. Can Vet J. 1995;36:184-185.

10. Niskanen R, Emanuelson U, Sundberg J, et al. Effects of infection with bovine virus diarrhea virus on health and reproductive performance in 213 dairy herds in one county in Sweden. Prev Vet Med. 1995;23:229-237.

11. Taylor LF, Janzen ED, Van Donkersgoed J. Losses over a 2-year period associated with fetal infection with the bovine viral diarrhea virus in a beef cow-calf herd in Saskatchewan. Canadian Vet J. 1997;38(1):23-28.

12. Rüfenacht J, Schaller P, Audigé L, et al. The effect of infection with bovine viral diarrhea virus on the fertility of Swiss dairy cattle. Theriogenol. 2001;56:199-210.

13. Wellenberg GJ, van der Poel WHM, Van Oirschot JT. Viral infections and bovine mastitis: a review. Vet Microbiol. 2002;88:27-45.

14. Coetzer JAW, Tustin RC. Bovine viral diarrhea and mucosal disease. In: Potgieter LND, editor. Infectious Disease of Livestock. 2nd ed. Oxford University Press. 2004:946.

15. Nettleton PF. Pestivirus infections in ruminants other than cattle. Rev Sci Tech. 1990;9:131-150.

16. Loken T. Ruminant Pestivirus infections in animals other than cattle and sheep. Vet Clin North Am Food Anim Pract. 1995;11:597-614.

17. Van Campen H, Froelich K, Hofmann M. Pestivirus infections. In: Williams ES, Barker IK, editors. Infectious Diseases of Wild Mammals. Ames: Iowa State University Press; 2001:232-244.

18. Grondahl C, Uttenthal A, Houe $\mathrm{H}$, et al. Characterization of a Pestivirus isolated from persistently infected mousedeer (Tragulus javanicus). Arch Virol. 2003;148:1455-1463. doi:10.1007/s00705003-0130-9

19. Braun U, Bachofen C, Büchi R, et al. Infection of cattle with Border disease virus by sheep on communal alpine pastures. Schweizer Archiv für Tierheilkunde. 2013;155(2):123-128. doi:10.1024/00367281/aOOO428

20. Wernery U. Bovine viral diarrhea- an emerging disease in camelids. A review. Am J Virol. 2012;1(1):9-17.

21. Evermann JF. Pestiviral infection of llamas and alpacas. Small Rumin Res. 2006;61:201-206.

22. Kapil S, Yeary T, Evermann JF. Viral diseases of new world camelids. Vet Clin Food Anim. 2009;25:323-337.

23. Shimeld LA Serological survey of alpacas living or breeding in Southern California. Proceedings of the 113th Annual Meeting of U.S.A Health Association, (HA' 09), San Diego. 2009; 1.

24. Kim SG, Anderson RR, Yu JZ, et al. Genotyping and phylogenetic analysis of bovine viral diarrhea virus isolates from BVDV infected alpacas in North America. Vet Microbiol. 2009;136:209-216.

25. Burgemeister R, Leyk W, Goessler R. Untersuchungen über Vorkommen von Parasitosen, bakteriellen und viralen Infektionskrankheiten bei Dromedaren in Südtunesien. Dtsch Tierärztl Wschr. 1975;82:352-354.

26. Bornstein S, Musa BE. Prevalence of antibodies to some viral pathogens, Brucella abortus and Toxoplasma gondii in serum from camels (Camelus dromedarius) in Sudan. J Vet Med. 1987;34:364-370. doi:10.1111/j.14390450.1987.tb00409

27. Bornstein S, Musa BE, Jama FM Comparison of seroepidemiological findings of antibodies to some infectious pathogens of cattle in camels of Sudan and Somalia with reference to findings in other countries of Africa. Proceedings of the International Symposium of Development of Animal Resources in Sudan, (DARS' 89), Khartoum. 1989; 28-34.

28. Bornstein S A disease survey of the Somali camels. SARE Report, Sweden. 1988; p1.

29. Zaghana A. Prevalence of antibodies to bovine viral diarrhea virus and or border disease virus in domestic ruminants. $J$ Vet Med. 1998;45(6):345-351. 
30. CSA (Central Statistical Authority of Ethiopia). Agricultural Sample Survey. Livestock and Livestock Characteristics. 2018:1-84

31. Moennig V, Liess B. Pathogenesis of intrauterine infections with bovine viral diarrhea virus. Vet Clin North Am Large Anim Pract. 1995; 11:477-487.

32. Khodakaram A, Farjanikish G. Persistent bovine viral diarrhea virus (BVDV) infection in cattle herds. Review Article. Iran J Vet Res. 2017;18(3):154-163.

33. Abdibari M, Dereje B, Samuel M, et al. Magnitude and factors associated with malnutrition in children 6-59 months of age in Shinille Woreda, Somali Regional State, Ethiopia: a cross-sectional study. BMC Nutrition. 2016;2:44.

34. Carlson JM, Ley BLV, Lee SI, et al. Detection of bovine viral diarrhea virus in stable flies following consumption of blood from persistently infected cattle. J Vet Diagn Invest. 2020;32(1):108-111. doi: $10.1177 / 1040638719898688$

35. Aragaw K, Sibhat B, Ayelet G, et al. Seroprevalence and factors associated with bovine viral diarrhea virus (BVDV) infection in dairy cattle in three milksheds in Ethiopia. Trop Anim Hlth Prod. 2018;50:1821-1827.

36. Radostits OM, Gay CC, Hinchcliff KW, et al. Veterinary Medicine. A Textbook of the Diseases of Cattle, Horses, Sheep, Pigs and Goats. Tenth ed. Elsevier, Edinburgh; 2007:1257-1284.

37. Mishra N, Pattnaik B, Vilcek S, et al. Genetic typing of bovine viral diarrhea virus isolates from India. Vet Microbiol. 2004;104:207-212. doi:10.1016/j.vetmic.2004

38. de Oliveira LG, Mechler-Dreibi ML, Almeida HMS, et al. Bovine viral diarrhea virus: recent findings about its occurrence in pigs: review. Viruses. 2020;12:600. doi:10.3390/v12060600

39. Sakhaee E, Khalili M, Kazeminia S. Serological study of bovine viral respiratory diseases in dairy herds in Kerman province, Iran. Iran $J$ Vet Res. 2009;10:49-53.

40. Nigussie Z, Tariku M, Tefera S, et al. Seroepidemiological study of bovine viral diarrhea (BVD) in three agro-ecological zones in Ethiopia. Trop Anim Hlth Prod. 2010;42:319-321.

41. Asmare K, Regassa F, Robertson LJ, et al. Reproductive disorders in relation to Neospora caninum, Brucella spp. and bovine viral diarrhea virus sero-status in breeding and dairy farms of central and southern Ethiopia. Epidemiol Infect. 2013;141(8):1772-1780.

42. Asmare K, Kassaye A, Berhanu S, et al. Serological evidence of bovine herpesvirus -1 , bovine viral diarrhea virus and schmallenberg virus infections in relation to reproductive disorders in dairy cattle in Ethiopia. Acta Trop. 2018;178:236-241.
43. Tadele T, Yosef D, Benti D. Seroprevalence of bovine viral diarrhea virus and its potential risk factors in dairy cattle of Jimma town, south western Ethiopia. J Dairy, Vet Anim Res. 2019;8(1):11-17.

44. Shirvani E, Lotfi M, Kamalzadeh M, et al. Seroepidemiological study of bovine respiratory viruses (BRSV, BoHV-1, PI-3V, BVDV, and BAV-3) in dairy cattle in central region of Iran (Esfahan province). Trop Anim Hlth Prod. 2012;44:191-195.

45. Gates M, Woolhouse M, Gunn G, et al. Relative associations of cattle movements, local spread, and biosecurity with bovine viral diarrhea virus (BVDV) and seropositivity in beef and in dairy herds. Pre Vet Med. 2013;112(3-4):285-295.

46. Probst C, Speck S, Hofer H. Epidemiology of selected infectious diseases in zoo ungulates: single species versus mixed species exhibits. Verh Erkrg Zootiere. 2007;43:10-12.

47. Wernery U, Thomas R, Raghavan R, et al. Sero-epidemiological studies for the detection of antibodies against infectious diseases in dairy dromedaries of the United Arab Emirates using modern laboratory techniques- part II. J Camel Pract Res. 2008;15(1):139-145.

48. Doyle LG, Heuschele WP. Bovine viral diarrhea virus infection in captive exotic ruminants. J. Am Vet Med Asso. 1983;183 (11):1257-1259.

49. Al-Afaleq A, Abu-Elzeim EME, Hegazy AA Sero-surveillance for antibodies against some viral diseases of livestock in camels (Camelus dromedarius) In Saudi Arabia. Proceedings of the International Scientific Conference on Camels, (ISSC '06), Qasim University, Kingdom of Saudi Arabia. 2006; 338-346.

50. Khawlah MIA. Detection of bovine viral diarrhea-mucosal disease (BVDMD) virus in dromedary camels in Iraq using ELISA. A preliminary study. Mirror Res Vet Sci Anim. 2016;5(1):70-74.

51. Peter ID, El-Yuguda AD, Mshelia GD, et al. Detection of bovine viral diarrhea virus antibodies in camels (Camelus dromedarius) in Maiduguri, Nigeria. Sokoto J Vet Sci. 2015;13(3):49-52.

52. Intisar S, Ali YH, Khalafalla AI, et al. The first report on the prevalence of Pestivirus infection in camels in Sudan. Trop Anim Hlth Prod. 2010;42(6):1203-1207.

\section{Publish your work in this journal}

Veterinary Medicine: Research and Reports is an international, peerreviewed, open access journal publishing original research, case reports, editorials, reviews and commentaries on all areas of veterinary medicine. The manuscript management system is completely online and includes a very quick and fair peer-review system. Visit http://www.dovepress.com/testimonials.php to read real quotes from published authors. 